\title{
ÉPÍTŐIPARI ANYAGOK HŐVEZETŐKÉPESSÉGÉNEK KÍSÉRLETI VIZSGÁLATA
}

\author{
Juhász Attila \\ jármümérnök BSc hallgató, Miskolci Egyetem \\ Áramlás- és Hötechnikai Gépek Intézeti Tanszék \\ Miskolc-Egyetemváros, Miskolci Egyetem,e-mail: juhaszattila1216@gmail.com \\ Szaszák Norbert \\ adjunktus, Miskolci Egyetem, Energetikai és Vegyipari Gépészeti Intézet \\ Áramlás- és Hötechnikai Gépek Intézeti Tanszék \\ 3515 Miskolc-Egyetemváros, Miskolci Egyetem, e-mail: aramszn@uni-miskolc.hu
}

\begin{abstract}
Absztrakt
Jelen dolgozatban különbözö - elsösorban épitöipari anyagok - hövezetésének vizsgálatára alkalmas kisérleti berendezést s annak müködését mutatjuk be, amely segitségével az anyagon belüli höterjedés az idö és a hely függvényében vizsgálható. Ehhez egy kisméretü, téglatest alakú höszigetelö kamra került összeállitásra, amelynek a belső légterét lezáró elem maga a próbatest. A kamra belsö terében egy digitális termosztát-egységgel beállitható a kivánt léghömérséklet, igy abban közel állandó hömérséklet hozható létre, amely a próbadarab hövezetés-mérésének egyikfeltétele. A kamra hövezetése jóval kisebb a vizsgált test hövezetésétöl, ezért a höáram jelentös része a próbatesten keresztül áramlik a környezetbe. A próbatest különbözö poziciójú és mélységü pontjaiban höelemek kerültek beépitésre, amelyek feszültségjeleit az idö függvényében számitógépen rögzitjük. Az adatfeldolgozással kapott hömérsékletidö függvények alapján a próbatest több hötani jellemzője is meghatározható.
\end{abstract}

Kulcsszavak: hövezetés, höszigetelés, termodinamika

\begin{abstract}
In this study, an instrument for examination of the heat conductivity of-mainly-construction materials is presented. The heat flow within the material can be examined both in the function of time and spatial position with this instrument. For this purpose, a small heat-insulated chamber with digital thermostat was constructed in which the temperature of the air can be set. The quasi constant temperature allows that the heat-conduction of a specimen placed in a part of the chamber-designed for this purposecan be determined. The heat conductivity of the chamber is much lower than that of the specimen thus almost all of the heat flow goes through the specimen. Thermocouples were placed in several positions and depth of the specimen. The time series of the signals of the thermocouples were acquired with computer. As a result of the data processing of the time series of temperature values the thermal characteristics of the specimen can be determined.
\end{abstract}

Keywords: thermal conduction, thermal insulation, thermodynamics 


\section{Bevezetés}

Az épületek fütésére és klimatizálására rengeteg energiát fordítunk. Ezt a pazarló magatartást megelőzhetnénk azzal, ha már az építőipari anyagokat is úgy válogatnánk meg, hogy alacsony hővezetésủ egységet alkossanak. Továbbá a szigetelőanyagokat is könnyebben tudnánk megválasztani, ha látnánk, melyik szigetelőanyag, szigetelő anyagkombináció milyen hővezetéssel rendelkezik. Elsődlegesen e menynyiség mérése céljából építettük meg saját vizsgálóberendezésünket és mérörendszerünket is.

A szilárd testekben lejátszódó hővezetési folyamatokat a legtöbb esetben az okozza, hogy azok a felszíni hőmérsékletüktől eltérő hőmérsékletű folyadékkal (gázzal) érintkeznek. Newton különböző fémtárgyak lehülésének tanulmányozása során állította fel azt az összefüggést, amely leírja a szilárd test felülete és az azzal érintkező fluidum közötti hőcserét, ezért a jelenséget leíró törvényszerüséget Newton-féle hőátadási törvénynek nevezik [1].

A hővezetés, mint jelenség igen gyakori a müszaki életben, viszont megértése nem túl egyszerü. Ennek segítése érdekében például Padrah et al. [2] létrehoztak egy olyan szemléltető berendezést, ami viszonylag gyorsan, kevesebb, mint két óra alatt képes adatokat szolgáltatni a vizsgált anyag hővezetéséről. Ehhez egy, a „hot plate” elven müködő rendszert hoztak létre. A gyors és szemléletes mérés az oktatást segíti, és egyben a hővezetés könnyebb érthetőségét is.

Célunk egy olyan mérőrendszer összeállitása volt, amellyel különböző próbatestekben, elsősorban építési anyagokban a rajtuk átáramló hőenergia hatására kialakuló hőmérsékletmezők időbeni változását tudjuk vizsgálni [3].

\section{A mérőrendszer}

A mérőrendszer fö vizsgálati egysége egy téglatest alakú hőszigetelt kamra, amely külső méretei $600 \times 600 \times 650 \mathrm{~mm}$. A kamra képes automatikusan egy előre beállított hőmérsékletet tartani, egy megadott, min. $\pm 0,1^{\circ} \mathrm{C}$-os hőfok-hiszterézissel. Ehhez a kamra belső terében egy elektromos hőforrás került beépítésre, amelyről a hő nagy része kényszerkonvekcióval, ventilátor segítségével jut el a belső légtér minden egyes pontjába. A kamra belső légterében, annak több pontjában, hőelemek segítségével mérjük a hömérsékletet.

Az 1. ábra jobb oldali részén a termosztát modul látható, amely a szigetelt kamra fontos eleme. Ehhez a modulhoz tartozik egy hőelem, amely a kamra belsejében került elhelyezésre, annak belső felületeitől megközelítőleg $50 \mathrm{~mm}$ távolságra. A belső hőmérséklet beállítása a belső tér villamos fütésének be/kikapcsolásával történik, amelyet a termosztát-modulon található relé vezérel. A fütőtest praktikus okokból egy $40 \mathrm{~W}$ teljesítményü hagyományos izzó. A légkeringtetésért és a kényszerkonvekcióért egy $12 \mathrm{~V}$ os, $1,5 \mathrm{~W}$-os axiális ventilátor felel, amely folyamatosan üzemel a lehető leghomogénebb hőmérsékletmező elérése céljából (lásd az 1. ábra bal oldali része). Melegítéskor, a kívánt hőmérséklet elérésekor a modul egy relé segítségével kikapcsolja a villanykörtét. Viszont abban az esetben, ha a rendszer elkezd hűlni a környezet felé áramló hőmennyiség miatt, s így a hőmérséklet a beállítottól a hiszterézis-értékkel $\left(0,1^{\circ} \mathrm{C}\right)$ eltér, a termosztát visszakapcsolja az izzót, így tehát a ki- és bekapcsolgatással közel állandó hőmérsékletet tart a rendszer.

A mérni kívánt próbatest (lásd az 1. ábra jobb oldala) a kamrának erre a célra kialakított nyílásába helyezhető (a kamrába beépített teherviselő vázra ültethető), ezáltal magának a kamrának a lezárása is megtörténik. A vizsgálatok során mind a kamra belső terében és a külső környezetben, mind pedig a próbatestbe beépített, továbbá annak belső és külső felületein elhelyezett hőelemekkel összesen húsz pontban mérjük a hőmérsékleteket (lsd. 1. ábra jobb oldali része). A hőelemek feszültségjeleinek gyüjtése Phidget adatgyüjtő rendszer segítségével történik, amely központi modulja USB porton keresztül 
csatlakozik a mérőszámítógéphez, ami az időben folyamatosan mintavételezett adatokat egy text file-ba menti a későbbi adatfeldolgozás céljából.

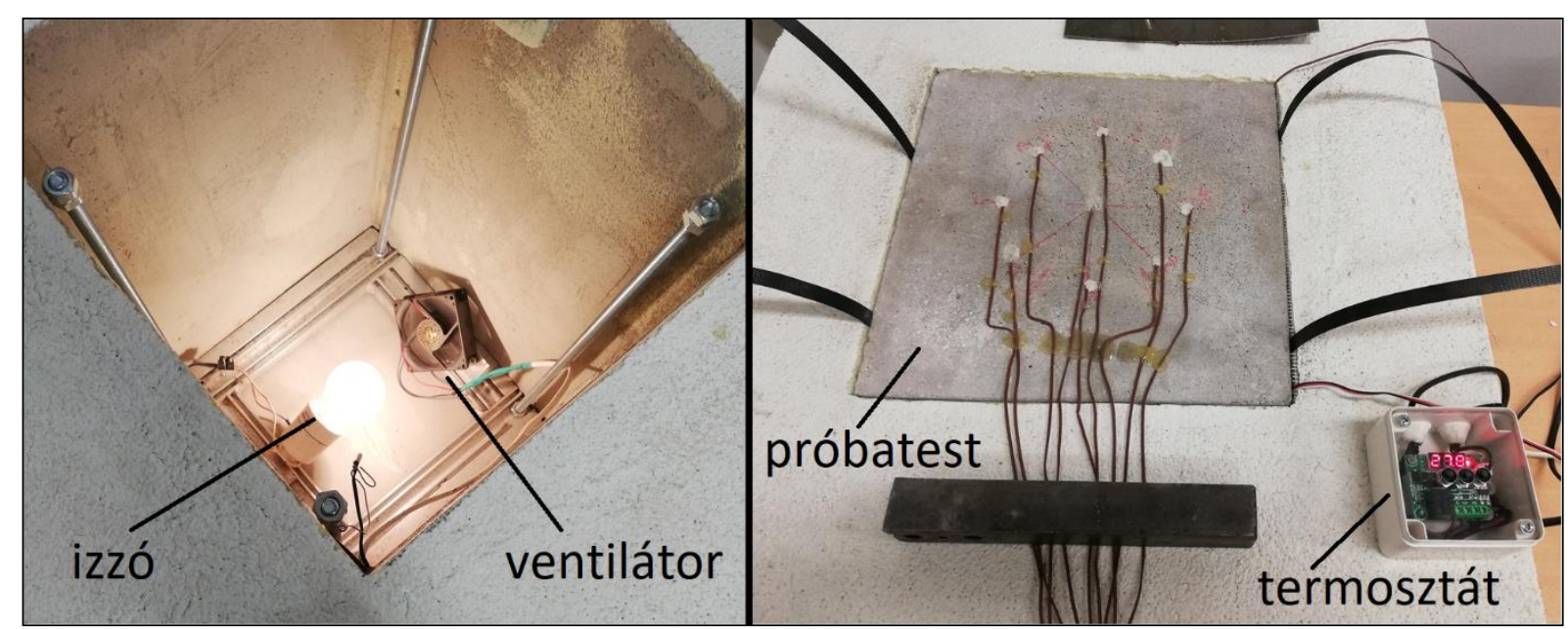

1. ábra. A kamra belső tere (balra) és a kamrába illesztett próbatest a kamrát vezérlö termosztáttal (jobbra).

\section{Tesztmérés}

Az összeállított mérôrendszer tesztelése céljából egy habosított betontömböt $(300 \times 300 \times 40 \mathrm{~mm})$ használtunk próbatest gyanánt, amelyen - annak négyzet felületű lapján - a felszíntől mérve $5 \mathrm{~mm}$-es lépésközzel egy kör mentén különböző mélységekben helyeztük el a K-típusú hőelemeket (lásd az 1. ábra jobb oldali képén). Ilyen módon a betontömb esetében összesen kilenc: nyolc belső, továbbá két felületi hőmérő pontot alakítottunk ki. A vizsgálat kezdetén a kamra belső terének és a próbatestnek a hőfoka megegyezett a környezeti hőmérséklettel, ami $20^{\circ} \mathrm{C}$-os volt. Mind a belső tér, mind pedig a környezet hőmérsékletét regisztráltuk. A mérés kezdetén $90^{\circ} \mathrm{C}$-ot állítottunk be a termosztáton, amely hőmérsékletre való felmelegítés során az folyamatosan müködtette a fütésért felelős izzót. A $40 \mathrm{~W}$-os izzóval és az adott hővezetésủ próbatesttel az elérhető maximális belső hőmérséklet jó közelítéssel $88,5^{\circ} \mathrm{C}$-ra adódott: e hőmérséklet esetén már csupán $0,1^{\circ} \mathrm{C} / \mathrm{min}$ melegedés volt regisztrálható. Ebben az állapotban a kamra teljes hővesztesége éppen $41,5 \mathrm{~W}$ értékủ volt, tehát a bevezetett hőteljesítménnyel megegyező hőáram hagyta azt el. Az adott, állandó teljesítményü hőbevezetéssel ez az állandósult állapot közel 8 és fél óra alatt volt elérhető. Ennek oka a kamrában található részegységek és a levegő, a kamra anyagának, továbbá a vizsgált próbatestnek a hőkapacitása volt. Ahhoz, hogy a vizsgált test hővezetése jó közelítéssel meghatározható legyen, stacioner állapotban szükséges ismerni az adott höfokkülönbség esetén a rajta átáramló hőteljesítményt. Ehhez ismerni kell a rendszerbe bevezetett hőteljesítményt, továbbá a kamra falán veszteségként kiáramló hőteljesítményt. A bevezetett hőteljesítmény egyszerü teljesítménymérő müszerrel könnyen mérhető, mivel az teljes egészében a rendszerbe vezetett elektromos teljesítményből adódik; azonban a veszteség-teljesítmény meghatározása még nem történt meg. Ennek meghatározása céljából a későbbiekben egy olyan próbatest kerül beépítésre, amely anyaga és falvastagsága megegyezik a kamra hőszigetelő falával. Így különböző fütési teljesítmények esetén a stacioner állapotot elérve meghatározhatók az egyensúlyi hőmérsékletek, amelyek ismeretében függvénykapcso- 
lat írható fel a veszteségteljesítmény és a hőfokkülönbség között. E függvény ismeretében pedig a vizsgált próbatest esetén kialakuló egyensúlyi hőmérséklet-különbségből kalkulálható az aktuális veszteségteljesítmény, tehát a próbatesten átáramló hőteljesítmény is.

Első lépésként célunk az összeállított mérörendszer müködésének tesztelése volt. Ehhez az előzőekben bemutatott próbatestet preparáltuk és építettük be a mérőkamrába. A közel 8 és fél órán keresztül másodpercenként mintavételezett hőmérséklet-adatokat később a MATLAB szoftverrel dolgoztuk fel. A 2. ábra a mért hőmérsékleti értékek időbeni alakulása látható a vizsgálat teljes időtartama alatt.

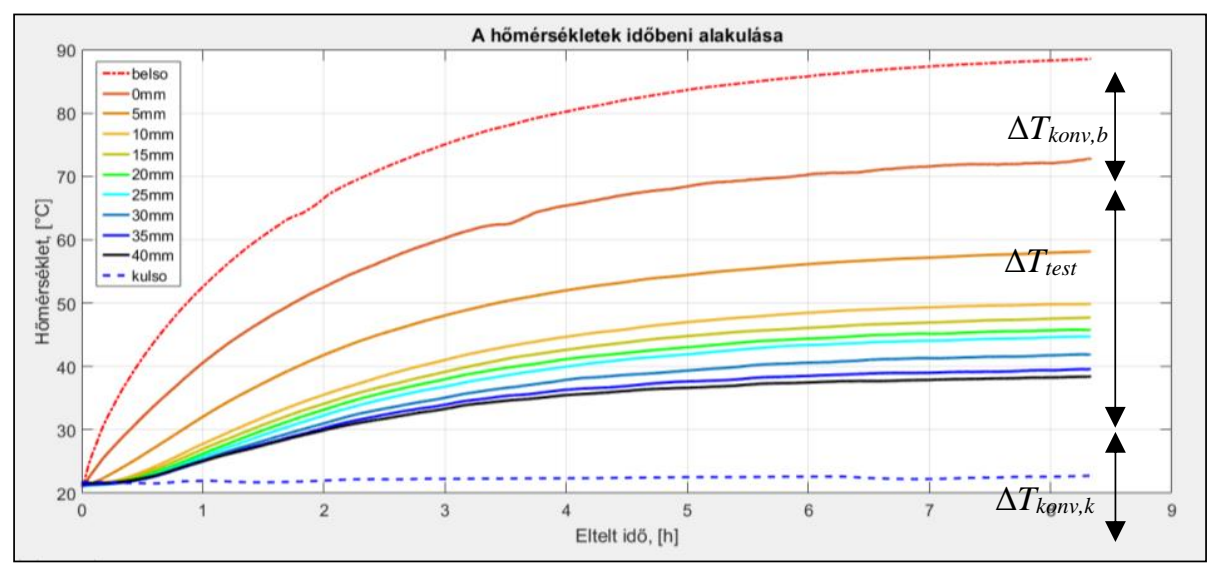

2. ábra. A hömérsékletértékek idöbeni alakulása.

A 2. ábra alapján több fontos megállapítás is tehető. A diagramon jelölt szaggatott vonal a külső levegő (környezet) hőmérsékletét mutatja, amely jó közelítéssel állandó értékủ volt. A későbbi mérések során a külső környezet hőmérséklete és páratartalma az adott feladatnak megfelelően beállítható lesz, miután a mérőegység egy klímakamrába kerül behelyezésre. A diagramon látható összes görbe meredeksége közel zérus értéküre csökken a mérés végéhez közeledve, amely jelzi az időben stacionárius hőáramlás kialakulását, tehát ekkortól már a teljes bevezetett hőáram megegyezik a környezet felé leadott hőáram értékével; a kamra és a próbadarab hőkapacitása már nem befolyásolja a rendszerből kilépő hőáram értékét. A legmagasabb hőmérsékletértékek a pontvonallal jelölt belső levegöhöz tartoznak, amelyet közvetlenül a kamrában elhelyezett villamos fütés melegített. Ez a ventilátorral keringtetett levegő melegítette konvekció segítségével a próbatest belső felületét, amelyhez tartozó höfokgörbe a diagramon a „0 mm”-es görbének felel meg (lásd a 2. ábra látható jelölésjegyzék). E görbe bármely időpillanatban a „belso” görbe alatt helyezkedik el, amelynek oka a hőátadás során kialakuló hőfoklépcső. Hasonló a helyzet a próbatest külső felülete („,40 mm”) és a környezeti levegő hőfoka („,kulso”) között. A 8. órától jó közelítéssel stacioner folyamat esetén a levegő hőmérséklete és a felület hőfoka közötti hőfoklépcsők ( $\Delta T_{k o n v, b}$ és $\Delta T_{k o n v, k}$ lásd a 2. ábra) a Newton-féle hőátadási törvényböl származtatva írható fel:

$$
\Delta T_{k o n v, i}=\frac{\dot{q}}{\alpha_{i}},
$$

ahol $\dot{q}$ a vizsgált próbatesten átáramló hőáram sűrüsége $\left[\mathrm{Wm}^{-2}\right]$ (egydimenziós hőáramlást feltételezve), $\alpha_{i}$ pedig a belső $(\mathrm{i}=\mathrm{b})$ és külső $(\mathrm{i}=\mathrm{k})$ höátadási tényező $\left[\mathrm{W}\left(\mathrm{m}^{2} \mathrm{~K}\right)^{-1}\right]$, amelyek értéke többek között a levegő áramlási sebességétől és a felület érdességétől is függ. Jelen mérési összeállítás esetén a hőátadási tényezők a számított hőáramsürüségből és a hőfoklépcsőkből kalkulálhatók. 
A próbatest hővetezési tényezője $(\lambda)$ egydimenziós hővezetést feltételezve a Fourier-féle hővezetési törvény egydimenziós alakja alapján számítható, átrendezve az alap összefüggést:

$$
\lambda=\frac{\dot{q} \cdot \delta}{\Delta T_{\text {test }}}
$$

ahol $\Delta T_{\text {test }}>0^{\circ} \mathrm{C}$ a próbatest két felületének hőfokkülönbsége stacionárius esetben és $\delta=40 \mathrm{~mm}$ a falvastagság (lásd 2. ábra).

Mindezek alapján tehát a vizsgált test hővezetési tényezőjének meghatározásához szükséges még a $\dot{q}$ hőáramsürüség értéke is, amelyet a próbatest hőáramlásra merőleges felületének ismeretében $\left(A_{t e s t}\right)$ a következő összefüggésből számíthatunk:

$$
\dot{q}=\frac{\dot{Q}}{A_{\text {test }}} .
$$

A (3) összefüggésben szereplö $\dot{Q}$ hőteljesítmény pedig nem más, mint a próbatesten időegység alatt átáramló hőmennyiség. Ez az előzőekben leírtak alapján a stacioner állapot elérése esetén megegyezik a rendszerbe bevezetett $\dot{Q}_{b e}$ hőteljesítmény és a veszteségként abból nem a próbatesten keresztül kilépő $\dot{Q}_{\text {veszt }}$ hőteljesítmény különbségével:

$$
\dot{Q}=\dot{Q}_{b e}-\dot{Q}_{v e s z t} .
$$

A hőveszteséget a korábbiakban leírt módon kívánjuk meghatározni a kamra falával megegyező tulajdonságokkal rendelkező próbadarab vizsgálatával. Ez a mérési módszer az úgynevezett „abszolút technika" [4].

A 2. ábra a próbatest különböző mélységü pontjainak függvényei $(, 0 \mathrm{~mm}$ - „,40 mm”) alapján további fontos megállapítás is tehető. Megfigyelhető, hogy a belső felülettől (,0 mm”) minél távolabbi pont hőmérséklet-görbéjét vizsgáljuk, időben annál később kezd el nőni annak hőfoka. Ez a 0-0,5 óra időintervallumban figyelhető meg leginkább. Ebben az időintervallumban a próbatestbe a kamra belső tere felől belépő hőáramnak az egyre kisebb része jelenik meg távolodva annak belső felületétől a külső felülete felé, ami miatt a hőmérséklet is késve kezd el emelkedni időben a belső hőmérséklethez képest. Ennek oka feltételezhetően a vizsgált test hőkapacitásában keresendő: instacioner esetben - egydimenziós hőáramlást feltételezve - a testbe belépő hőáram folyamatosan csökken a testen történő áthaladása közben, hiszen a hőenergia egy része a test anyagának felmelegítését szolgálja. Így tehát a test külső felületén csak időben eltolva, annak fajlagos hőkapacitásától (fajhőjétől) és térbeli dimenzióitól függően jelenik meg az a hőáram, amely a belső felületen a testbe belépett. Ennek az időben való eltolódásnak fontos hatása van az építőanyagok esetében. Egy nagyobb hőkapacitással rendelkező építőanyagon nagyobb idő alatt tud csak ,átjutni” az egyik oldalán közölt hő, így a másik felületen időben csak később jelenik meg a hőmérséklet-változás. Ez a napi hőfok-ingadozás esetén egy hőmérséklet-kiegyenlítő hatást eredményez. Jól megválasztott építőanyag (hővezetési tényező és hőkapacitás) és építőanyag-vastagság esetén a belső térben a falhőmérséklet ingadozása jelentősen lecsökkenthető. Hasonló elvet alkalmaznak a régi építésü, nagy tömegü vályogházak is. Mivel a hőkapacitás értéke összefüggésben áll a próbatest különböző mélységü pontjaiban mért hőmérséklet-értékek időbeni alakulásával, ezért az általunk készített berendezést a jövőben képessé kívánjuk tenni a nevezett mennyiség meghatározására is. Az adatfeldolgozás pontosítása érdekében hasonló problémával foglalkozó munkából vett eljárásokat is be kívánunk abba illeszteni. 


\section{4. Összefoglalás}

Az összeállított mérörendszerrel a saját készítésű hőszigetelt kamrába beépített próbadarabon elvégzett mérés eredményei alapján elmondható, hogy a rendszer alkalmas különböző anyagok hővezető képességének meghatározására. A mért mennyiségek feldolgozásával meghatározhatóvá válik a próbatest hövezetési tényezője, ami a mérőrendszer összeállításának elsődleges célja volt.

A későbbiekben a próbatest hőkapacitásának meghatározása céljából kívánjuk továbbfejleszteni a rendszert. Mivel maga a vizsgálókamra kisméretű, így az behelyezhető a Tanszék laboratóriumában található klímakamrába, amelyben szimulálható a napi hőingadozás hatása is. Az elkövetkezőkben a mérések mellett a jelenségek pontosabb vizsgálata céljából numerikus szimulációkkal (ANSYS Fluent) is ki kívánjuk egészíteni vizsgálatainkat.

\section{Köszönetnyilvánítás}

Köszönet illeti Farkas László műszaki szolgáltatót és Bozzay Péter tanszéki mérnök kollégát, akik a mérőrendszer összeállításában és az adatgyüjtés automatizálásában nyújtottak segítséget. A cikkben ismertetett kutatómunka az EFOP-3.6.1-16-2016-00011 jelü „Fiatalodó és Megújuló Egyetem - Innovatív Tudásváros - a Miskolci Egyetem intelligens szakosodást szolgáló intézményi fejlesztése" projekt részeként - a Széchenyi 2020 keretében - az Európai Unió támogatásával, az Európai Szociális Alap társfinanszírozásával valósul meg.

\section{Irodalomjegyzék}

[1] Bihari, P.: Müszaki hőtan, Edutus Főiskola, Budapest, 2012.

[2] Padrah, I., Pásztor, J., Farmos, R.: Hövezetés jelenségét tanulmányozó berendezés tervezése és kivitelezése, Müszaki Tudományos Közlemények, vol. 11., 2019., pp. 153-156. https://doi.org/10.33895/mtk-2019.11.34

[3] Jónás, Z.: Hövezetési tényezö mérése polisztirol habokban, Erdélyi Múzeum-Egyesület, Müszaki Tudományos Füzetek - FMTÜ, 1998. pp. 257-260.

[4] Dongliang, Z., Xin, Q., Xiaokun, G.: Measurement Techniques for Thermal Conductivity and Interfacial Thermal Conductance of Bulk and Thin Film Materials, Univ. of Colorado, Boulder, 2017., pp. 5-10. 